\title{
LITHUANIAN HEALTH PROTECTION SYSTEM IN COMPARISON WITH COUNTRIES OF BALTIC SEA REGION
}

\author{
Dalia ŠTREIMIKIENĖ \\ Mykolas Romeris University \\ E-mail: daliastreimikiene@mruni.eu \\ Justas ŠTREIMIKIS \\ Lithuanian University of Health Sciences \\ E-mail: Justas.streimikis@gmail.com \\ doi:10.13165/IE-13-7-2-02
}

\begin{abstract}
Improving health conditions of population and development of effective health protection system is the main social target of sustainable development. An effective system for public health care aims to ensure adequate health care and improvement in population's health status. However, investments in the health policy, improving the competencies of public health specialists, infrastructure development, the building of the communities' health improvement capacities, etc., provide for different results in the Baltic Sea Region countries. Therefore, it is important to analyse the efficiency of health protection systems in the Baltic Sea Region and to define the main factors having impact on health status in specific countries.

The aim of the presentation is to review health care resources and health protection systems' impacts on the health status in Lithuania and other countries in the Baltic Sea Region. The main tasks in order to achieve this aim are:

- To compare health care resources and state financing of health protection systems in Lithuania and other Baltic Sea Region countries;

- To compare health indicators in Lithuania and other Baltic Sea Region countries;a

- To define the efficiency of health protection systems in Lithuania and other Baltic Sea Region countries in terms of achievements in improving health status of the population;

- To analyse Lithuanian health protection system and to identify the major gaps and drawbacks;

- To discuss the results and findings.
\end{abstract}

JEL classification: I15, I18, H42, H52.

Keywords: comparative assessment, Lithuanian health protection, Baltic Sea Region.

Reikšminiai žodžiai: sveikatos apsaugos sistema, sveikatos būkles rodikliai, Baltijos jūros regionas, lyginamoji analizè. 


\section{Introduction}

Improving health conditions of population and development of effective health protection system is the main social target of sustainable development. In Lithuania, more and more attention is being devoted to modern public health and its strengthening based on cooperation among social partners. An effective system for public health care and control is being developed with an emphasis on healthy lifestyle and creation and preservation of a healthy environment, with the aim to ensure adequate health care based on the international experience and scientific evidence. Residents are receiving more information on ways to maintain good health and to prevent diseases and they are showing more concern regarding health effects on the environment and healthy lifestyle. However, investments in the health policy, improving the competencies of public health specialists, infrastructure development, the building of the communities' health improvement capacities as well as the analysis of the impact of social and economic factors are insufficient. Stronger efforts are needed to include the health policy objectives in the economic strategies as well as in the regional and the self-government policies. There should be more cooperation among health, social security, education and law enforcement institutions when dealing with public health care issues. The criteria for planning the Lithuanian State budget allocations for public health care have not been established. There is a shortage of mechanisms promoting concentration of health improvement resources and health investments. Legal definition of economic liability for the negative effects of economic activities is necessary.

The investments in the health policy, improving the competencies of public health specialists, infrastructure development, the building of the communities' health improvement capacities, etc., provide for different results in the Baltic Sea Region countries. Therefore, it is important to analyse the efficiency of health protection systems in Lithuania and other countries of the Baltic Sea Region and to define the main factors having impact on health status in specific countries.

The aim of the presentation is to review health care resources and health protection systems and other health determinant impacts on the health status in the Baltic Sea Region.

The main tasks are to compare health care systems, resources and state financing of health protection systems in the Baltic Sea Region countries as well as health determinants and health status indicators of the Baltic Sea Region countries and to assess the efficiency of the health protection system in Lithuania in comparison with the Baltic Sea Region countries.

\section{Models of health protection system}

Health care of health protection system can be characterized by a specific model. The model provides for different results in ensuring health status in the country. Usually, the healthcare models are divided into 5 groups: the Bismarck model, the Beveridge model, the Semashko model, the National health insurance model and the 'out of pocket' model. Such a division builds on characteristics of financing and employs the principle 
that health system's organization is largely determined by healthcare financing. This division is still useful for a comparative analysis of the health protection systems. The models of organization of social protection systems also fit well for the analysis of the health protection systems, as they are included in the social protection system, as well.

Countries with the social insurance model in healthcare are automatically ascribed to the Bismarck model (e.g. Germany). The system uses an insurance system - the insurers are called "sickness funds" usually financed jointly by employers and employees through payroll deduction. The Bismarck-type health insurance plans have to cover everybody, and they do not make a profit. Doctors and hospitals tend to be private in Bismarck countries. Although this is a multi-payer model, Germany has about 240 different funds - tight regulation gives the government much of the cost-control clout that the single-payer Beveridge model provides. The Bismarck model is found in Germany, France, Belgium, the Netherlands, Japan, Switzerland and, to a degree, in Latin America.

The Beveridge model is based on the idea that health care is provided and financed by the government through tax payments, just like the police force or other public goods. According to this model, many, but not all, hospitals and clinics are owned by the government; some doctors are government employees, but there are also private doctors who collect their fees from the government. This system tends to have low costs per capita because the government, as the sole payer, controls what doctors can do and what they can charge. Countries using the Beveridge plan or variations on it include its birthplace Great Britain, Spain, most of Scandinavia and New Zealand.

The Semashko health care model is an extreme case of the Beveridge model. This model was developed and applied in the former Soviet Union. The Semashko model was highly centralized with the key decision-making and planning. The main features of it were as follows:

- The health care system was under the centralized control of the state, which financed services by general government revenues as part of national social and economic development plans.

- All health care personnel became employees of the centralized state, which paid salaries and provided supplies to all medical institutions.

- The main policy orientation throughout this period was to increase numbers of hospital beds and medical personnel.

The National health insurance model has elements of both Beveridge and Bismarck models. It uses private-sector providers, but payment comes from a government-run insurance program that every citizen pays into. The single payer tends to have considerable market power to negotiate for lower prices. The National Health Insurance plans also control costs by limiting the medical services they will pay for or by making patients wait to be treated.

Only the developed, industrialized countries - perhaps 40 of the world's 200 countries - have established health care systems. Most of the nations on the planet are too poor and too disorganized to provide any kind of mass medical care. The basic rule in such countries is that only the rich get medical care; the poor stay sick or die. This type of health protection system is called the 'out of the pocket' model.

Table 1 provides the health care models and allocates the Baltic Sea region countries to the specific health care models. 
Table 1. Health care models and distribution of the Baltic Sea region countries

\begin{tabular}{|l|l|l|l|l|}
\hline \multicolumn{1}{|c|}{ Models } & $\begin{array}{c}\text { The Bismark } \\
\text { model }\end{array}$ & \multicolumn{1}{|c|}{$\begin{array}{c}\text { The Beveridge } \\
\text { model }\end{array}$} & $\begin{array}{c}\text { The National health } \\
\text { insurance model }\end{array}$ & $\begin{array}{c}\text { The Semashko } \\
\text { model }\end{array}$ \\
\hline $\begin{array}{l}\text { Countries ap- } \\
\text { plying a specific } \\
\text { model }\end{array}$ & Germany & $\begin{array}{l}\text { Finland, Sweden, } \\
\text { Denmark, Iceland, } \\
\text { Norway }\end{array}$ & $\begin{array}{l}\text { Estonia, Latvia, } \\
\text { Lithuania, Poland }\end{array}$ & Russia \\
\hline
\end{tabular}

The concept of the Nordic welfare state model is well defined and internationally recognized. While the health care sector is recognized as an integral part of the welfare state model in all Nordic countries, the concept of the Nordic model of health care is less recognized and also less well defined. Two common goals - equity and public participation - have led the Nordic countries to develop health care systems that share several structural and institutional similarities. The Nordic countries belong to the family of public integrated single-payer health care systems. Similar to other countries, which use the Beveridge model, the Nordic health care systems are predominantly tax-funded health systems with only minor supplementary premium-based or 'out-of-pocket' financing. In the Nordic case, private health insurance has often been marketed as a way to improve timeliness of access rather than reduce the public costs of care. Denmark is the country with the largest share of supplementary insurance, in part a legacy from its recent history (up until 1972) of social insurance. The governance structure of the Nordic countries has been (and is) decentralized, with the responsibility for service provision resting on a regional, county or municipal level, although often within a framework of centralized supervision, regulation or coordination. There are, however, considerable differences between the countries, both in terms of degree of decentralization and the interaction between the different levels. Norway has different degrees of decentralization for primary and secondary care: the first being the responsibility of the municipalities and the second consisting of four regional health enterprises. Also, while tax funded, actual funding is a combination of locally raised (and regulated) taxes. Sweden, Denmark, Norway and Iceland are the world's leaders in health care. Health financing in the Russian Federation is a relatively even mix of financing from compulsory sources and 'out-of-pocket' payments. The coverage of the population is nominally universal, free and guaranteed as a constitutional right, however, the health care services provided are poor and functioning of the health care system is not efficient.

The Baltic States have similar health care systems to Poland. In 1990, Estonia implemented the insurance-based health care system. In 1991, Estonia had 22 local health insurance funds. In 1994, the number of local health insurance funds dropped to 17, and the Central Health Insurance Fund was established as a type of leveling fund controlled by the Health Insurance Council (made up of 15 members, including the representatives of the state, the employees and the employers). The consolidation of health care financing was finalized in 2002 with the establishment of the Estonian Health Insurance Fund, a public agency fully responsible for providing equal health insurance to all insured individuals. Throughout this time, the main source of financing for all health care services in Estonia has been the $13 \%$ tax on wages specifically earmarked for the health care (as part of the social tax) (Eesti Koosto Kogu, 2011). 
Latvia started the reform of the health care system with the option of combined financing from the state and local government budgets and then moved on to central financing from the state budget in 1998, although various formulae were still used to combine specific sources of financing and the size of the budget, and 8 regional health insurance funds were used to manage the system. It was only in 2005, when Latvia instituted a system, in which the health care was uniformly financed based on the social tax through a single National Health Insurance Agency, although health care expenditure is still combined with other forms of social expenditure (pensions, unemployment benefits, etc.), and the specific sum to be provided for the health care from the budget is separately agreed upon in parliament on an annual basis.

Lithuania introduced a system of health financing that was funded from various sources at the beginning of the 1990s. Health care institutions were financed from local budgets and the national budget, while the expenses on medicines were financed through the State Social Insurance Fund Board (SODRA). In 1997, Lithuania instituted a health insurance system centered around the National Patient Fund and 10 regional funds, which were initially financed using a relatively small insurance payment (3\% of wages), supplemented from the national budget based on the imputed income tax. Since 2003, there have been 5 regional funds, the size of the social tax collected by SODRA is determined by the parliament on a yearly basis and the budget for health care services is still compiled from various sources, which is decided on through political decision processes (Jakušovaite, Darulis, 2005; Kiskiene, S. Giest, 2010).

Therefore, over the past 20 years, the main difference in terms of the organization of health care financing in Estonia, Latvia and Lithuania has been the predictability of the health care budget. In other words, the difference lies in the degree, to which the financing entities and service providers are able to have an overview of the future finances and plan their revenue and expenditure in the medium term. In Estonia, even if the amount of money available has been insufficient, the health care system has enjoyed a degree of security and clarity regarding the future in the short term, since political events have had relatively little impact on the health care financing decisions. In Latvia and Lithuania, the financing schemes have often been changed and the level of financing provided for the health care has been determined on a yearly and mainly through a political process.

The analytical review in this paper will use a simple model for the assessment of health care systems, which will disclose relationships among system performance (services, resources and financing), health determinants (life style, obesity, etc.) and impact on ultimate outcomes (health status). Further, the paper will focus more on the situation in health protection in Lithuania, as the health status indicators in Lithuania are one of the worst among the Baltic Sea Region countries.

\section{System of health indicators}

The indicators framework for the assessment of the health protection system efficiency was created consisting from system performance indicators and impact indicators representing the health status (Patrick, Erickson, 1993). The system performance 
indicators consist of health care resources and health financing indicators. According to the World Health organization, the health status depends on 4 factors (World Health Organization Europe, 2010): health care system performance (20\%), environmental impact $(20 \%)$, inherited or genetic impacts $(10 \%)$ and life styles $(50 \%)$. The indicators on determinants of health, such as prevalence of obesity, alcohol and tobacco consumption, are also important. The determinants of health are tightly related with cultural factors, but in this paper the cultural issues will not be addressed. However, cultural differences have a significant impact not just on life styles, genetics and health status, but also on the efficiency of the health care system functioning (Perleth et al. 2001).

Figure 1 provides the system of indicators for the analysis of the effectiveness of the health protection system.

Figure 1. The system of health indicators

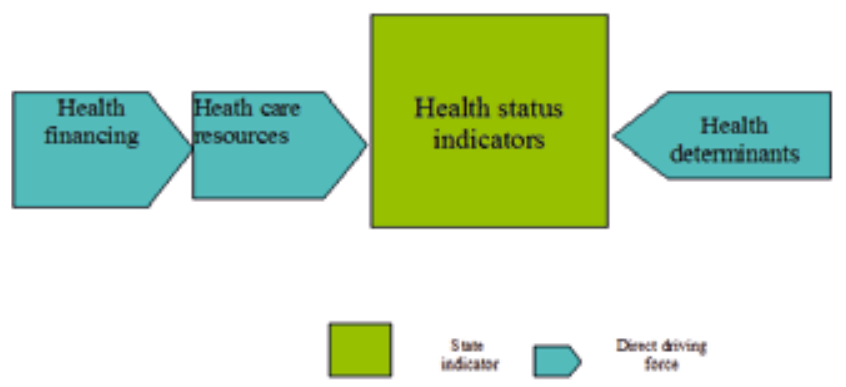

The health protection efficiency and the increase of health status of the population are the main aims of the health care policy of the Baltic Sea region. Therefore, the countries need to be compared according to the health status, health care resources, health financing and the determinant of health, seeking to define the most efficiently functioning health protection system. In Table 2, the main indicators of health are provided for the 11 Baltic Sea Region countries.

Table 2. Health indicators in the Baltic Sea Region countries in 2010

\begin{tabular}{|c|c|c|c|c|c|c|c|c|c|c|c|c|}
\hline & 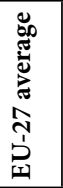 & & 茎 & 䓂 &  & 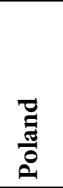 & 氖 & పี & 范 & 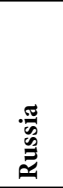 & 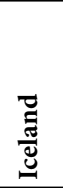 & 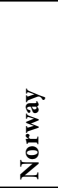 \\
\hline \multicolumn{13}{|c|}{ Health status } \\
\hline $\begin{array}{l}\text { Average life } \\
\text { expectancy at } \\
\text { birth }\end{array}$ & 79.7 & 72.1 & 73.0 & 73.3 & 80.1 & 76.0 & 80.2 & 81.3 & 78.7 & 67.2 & 80 & 80 \\
\hline $\begin{array}{l}\text { Females healthy } \\
\text { life years at } 65\end{array}$ & 20.1 & 18.3 & 18.1 & 19.2 & 21.4 & 19.3 & 20.8 & 21.1 & 19.6 & 16.5 & 21 & 21.1 \\
\hline $\begin{array}{l}\text { Males healthy } \\
\text { life years at } 65\end{array}$ & 16.5 & 13.4 & 13.2 & 13.9 & 17.4 & 14.9 & 17.6 & 18.2 & 16.8 & 12.0 & 18.4 & 17.9 \\
\hline
\end{tabular}




\begin{tabular}{|c|c|c|c|c|c|c|c|c|c|c|c|c|}
\hline $\begin{array}{l}\text { Infant mortality } \\
\text { rates, } 2010\end{array}$ & 4.2 & 4.3 & 5.7 & 3.3 & 2.3 & 5.0 & 3.4 & 2.5 & 3.4 & 9.0 & 2.2 & 2.8 \\
\hline $\begin{array}{l}\text { Adults self-re- } \\
\text { ported health } \\
\text { status, \% } 2010\end{array}$ & 67 & 52 & 49 & 53 & 69 & 58 & 65 & 80 & 71 & 46.0 & 78 & 77 \\
\hline $\begin{array}{l}\text { Transport acci- } \\
\text { dent mortality } \\
\text { rates, } 2010\end{array}$ & 7.7 & 12.8 & 10.8 & 8.1 & 5.9 & 11.0 & 4.4 & 3.8 & 5.5 & 24.7 & 4.2 & 5.2 \\
\hline $\begin{array}{l}\text { Suicide mortali- } \\
\text { ty rates, } 2010\end{array}$ & 12.3 & 31.5 & 20.7 & 18.3 & 16.8 & 15.4 & 9.9 & 12.3 & 9.9 & 23.0 & 11.5 & 11.5 \\
\hline $\begin{array}{l}\text { Mortality rates, } \\
\text { per } 100000 \\
\text { population }\end{array}$ & 663 & 964 & 951 & 840 & 574 & 776 & 565 & 520 & 644 & 1172 & 507 & 537 \\
\hline $\begin{array}{l}\text { Mortality ra- } \\
\text { tes, males per } \\
100000 \text { popu- } \\
\text { lation }\end{array}$ & 866 & 1418 & 1362 & 1246 & 755 & 1065 & 697 & 628 & 772 & 1400 & 604 & 657 \\
\hline $\begin{array}{l}\text { Ischemic heart } \\
\text { disease morta- } \\
\text { lity rates, males } \\
\text { per } 100000 \\
\text { population }\end{array}$ & 156 & 429 & 378 & 299 & 177 & 133 & 111 & 117 & 84 & 517 & 118 & 92 \\
\hline $\begin{array}{l}\text { All cancers } \\
\text { mortality ra- } \\
\text { tes, males per } \\
100000 \text { popu- } \\
\text { lation }\end{array}$ & 230 & 293 & 288 & 286 & 174 & 271 & 199 & 168 & 219 & 180 & 186 & 191 \\
\hline $\begin{array}{l}\text { All cancers inci- } \\
\text { dent rates, ma- } \\
\text { les per } 100000 \\
\text { population }\end{array}$ & 296 & 317 & 304 & 286 & 271 & 281 & 331 & 270 & 335 & 187 & 306 & 338 \\
\hline $\begin{array}{l}\text { Prevalence of } \\
\text { dementia , aged } \\
60 \text { and over, \%- }\end{array}$ & 5.5 & 5.3 & 5.2 & 5.4 & 5.6 & 5.3 & 5.9 & 6.3 & 5.6 & 1.4 & 5.5 & 6.4 \\
\hline $\begin{array}{l}\text { Prevalence of } \\
\text { tuberculosis, } \\
\text { per } 100000 \\
\text { population }\end{array}$ & 9.1 & 94 & 43 & 26 & 8.5 & 29.0 & 5.9 & 8.8 & 7.4 & 136 & 5.2 & 7.5 \\
\hline \multicolumn{13}{|c|}{ Determinants of health } \\
\hline $\begin{array}{l}\text { Smoking daily, } \\
\% \text { of population } \\
\text { among }\end{array}$ & 23 & 26.5 & 27.9 & 26.2 & 19.0 & 23.8 & 21.9 & 14.0 & 20.0 & 42.0 & 14.3 & 19.0 \\
\hline $\begin{array}{l}\text { Alcohol con- } \\
\text { sumption, liters/ } \\
\text { capita }\end{array}$ & 10.7 & 12.6 & 13.2 & 11.4 & 9.7 & 10.1 & 11.7 & 7.3 & 10.3 & 16.2 & 7.3 & 6.6 \\
\hline $\begin{array}{l}\text { Prevalence of } \\
\text { obesity, adults, \% }\end{array}$ & 16.6 & 19.7 & 16.9 & 16.9 & 15.6 & 15.8 & 14.7 & 12.9 & 13.4 & 29.8 & 21.0 & 10.0 \\
\hline
\end{tabular}




\begin{tabular}{|c|c|c|c|c|c|c|c|c|c|c|c|c|}
\hline \multicolumn{13}{|c|}{ Health care resources } \\
\hline $\begin{array}{l}\text { Practising doc- } \\
\text { tors, per } 1000 \\
\text { population }\end{array}$ & 3.4 & 3.7 & 2.9 & 3.2 & 3.3 & 2.2 & 3.7 & 3.8 & 3.5 & 4.3 & 3.6 & 4.1 \\
\hline $\begin{array}{l}\text { Hospital beds, } \\
\text { per } 1000 \text { popu- } \\
\text { lation }\end{array}$ & 5.3 & 6.8 & 5.3 & 5.3 & 5.9 & 6.6 & 8.3 & 2.7 & 3.5 & 9.7 & 5.8 & 3.3 \\
\hline \multicolumn{13}{|c|}{ Health expenditures and financing } \\
\hline $\begin{array}{l}\text { Health expendi- } \\
\text { ture per capita, } \\
\text { 2010, EUR PPPs }\end{array}$ & 2171 & 972 & 821 & 995 & 2504 & 1068 & 3337 & 2894 & 3439 & 757 & 2524 & 4156 \\
\hline $\begin{array}{l}\text { Total health } \\
\text { expenditure as } \\
\text { a share of GDP, } \\
2010\end{array}$ & 9.0 & 7.0 & 6.8 & 6.3 & 8.9 & 7.0 & 11.6 & 9.6 & 11.1 & 5.1 & 9.3 & 9.4 \\
\hline $\begin{array}{l}\text { Expenditures } \\
\text { private on phar- } \\
\text { maceuticals per } \\
\text { capita as a share } \\
\text { of GDP, \% }\end{array}$ & 1.6 & 1.9 & 1.5 & 1.4 & 1.2 & 1.6 & 1.7 & 1.2 & 0.8 & 1.5 & 1.5 & 0.7 \\
\hline
\end{tabular}

Source: OECD (2012).

Life expectancy is the main indicator of the health of the population (Johanesson et al., 1997). Other important health indicators are infant mortality (infant deaths against 1000 births), circulatory disease death per 100000 populations, death from cancer per 100000 populations, incidence of tuberculosis, obesity rate, etc. (European Observatory on Health Care Systems, 2000).

The differences between the countries of the Baltic Sea region are the greatest in terms of the life expectancy: neither the old nor the new EU member states constitute any kind of uniform group in this regard (Krupnick, Cropper, 1992). The life expectancy is lower in Denmark than in the other old EU countries and higher in Poland than in the Baltic States. Lithuania is ranked $80^{\text {th }}$ according to the life expectancy. The overall life expectancy in Lithuania is 72.1, man life expectancy reaches 67.5, whereas woman life expectancy is 78.3. The life expectancy in Russia lags considerably from all the Baltic Sea region countries. Whether longer life expectancy is accompanied by good health and functional status among ageing populations has important implications for health and long-term care systems. Higher life expectancy at the age of 65 is generally associated with higher HLY, although longer life expectancy at the age of 65 does not necessarily imply more HLY. The Baltic States and Poland have both lower life expectancy and HLY than the Nordic countries. Russia has the lowest HLY for males, following Lithuania. The highest HLY for females is in Norway. There is a big difference between HLY among males and females, especially in the Baltic States, i.e. females have about 5 years higher HLY than males.

According to infant mortality, Lithuania is ranked $145^{\text {th }}$ and the situation has significantly improved since 1995 from 12.4 to 5 infant deaths per 100 live births. Latvia is ranked $124^{\text {th }}$ and Estonia $134^{\text {th }}$, therefore, the situation in Lithuania in 2010 was better comparing with the neighboring countries. Japan has the best indicator, following by 
Iceland, Finland, Norway, etc. Russia has a very high infant mortality rate - 9 infant deaths per 100 live births.

According to adults' self-reported health status, in 2010 the lowest rate was in Russia $-46 \%$. Also, in Latvia only $49 \%$ of the population self-reported as being healthy. The healthiest population is in Sweden (80\%), Iceland (78\%) and other Nordic countries, having the higher indicators than EU-27 average. In Denmark more than 70\% and in Finland almost $70 \%$ of the population self-reported that they were healthy. Only $52 \%$ of the population reported about good health in Lithuania in 2010.

According to suicide rate and transport accident mortality rate, Lithuania is the world leader. Transport accidents mortality rate is an important indicator, representing the quality of institutions and enforcement of laws (Kidholm, 1995). Comparing with other EU member states, especially the Nordic countries, these indicators look frightening in Lithuania. Russia is ranked as the second worst performing country according to the suicide rate, following Lithuania. According to the transport accidents mortality rate, Russia is the world leader and has even twice higher transport accidents mortality rate than Lithuania.

According to diseases of the circulatory system and ischemic heart disease, Lithuania is in a very bad position, comparing with other countries. The situation has not changed since 1990, e.g., in Japan this indicator is 151 deaths per 100000 population and in Lithuania - 697.6 deaths per 100000 population. The best performing countries in the world according to this indicator are Japan, Switzerland, France and other old EU member states. According to the ischemic heart disease rate, Lithuania is the second among the Baltic Sea Region countries, following Russia, e.g., in Lithuania the ischemic heart disease mortality rate is 429 deaths per 100000 population for males comparing with Denmark - 84 deaths per 100000 population for males.

Deaths from cancer have increased almost twice in Lithuania during the period of 1990-2009. The current indicator - 293 deaths per 100000 population - is lower comparing with some developed countries, however, these indicators are lower in the Nordic countries. The worst performing country according to this indicator is the Netherlands (433 deaths per 100000 population). Cancer incidence rates in the Nordic countries are higher than in Lithuania, but cancer mortality rates are significantly lower, indicating the high efficiency of cancer treatment.

According to incidences of tuberculosis per 1000000 population, Lithuania is ranked $98^{\text {th }}$ (94 per 100000 population), Latvia $-97^{\text {th }}$ and Estonia $-117^{\text {th }}$. Russia has even a worse situation in this field and has a rate of 136 per 100000 population. The best performing country according to this indicator is Iceland (5.2 per 100000 population). The worst performing countries are in Africa, starting from Swaziland and following by Namibia, Botswana, etc. The Nordic countries have the lowest indicators for incidences of tuberculosis.

Indicators of prevalence of dementia aged 60 are higher for the Nordic countries, comparing with the Baltic States and Russia. This is the only health indicator, except for the cancer incident rate, which is higher in the Nordic countries, comparing with the Baltic States and Russia.

Health determinants indicators, such as alcohol or tobacco consumption and obesity, are the worst in Russia and Lithuania, following by Latvia, Estonia and Poland. The Nordic countries are the leaders in the health determinants indicators, except several like alcohol consumption or prevalence of obesity, which are quite high in Iceland. Cultural 
issues need to be studied in more detail to reveal the differences in health determinants between the Baltic Sea Region countries.

As it can be seen from Table 2, in 2010 the EU member states devoted an average of $9.0 \%$ of their GDP to health spending. Germany allocated $11.6 \%$ in terms of health spending per capita, whereas Denmark (EUR 3 439) was among the highest spenders among the EU member states with Germany being the following one, spending over 3000 EUR per capita. Russia has the lowest spending with around 757 EUR per capita. Comparing the main health indicators between Lithuania and other Baltic Sea Region countries, very low health expenditure rates per capita can be noticed in Lithuania, which makes 972 EUR adjusted at PPP or 7\% of GDP. In Denmark, health expenditures per capita in 2010 were equal to 3439 EUR PPPS or 9\% of GDP. Only in Latvia health expenditures were lower than in Lithuania and made 821 EUR PPPs or $6.8 \%$ of GDP. In Lithuania, adults' self-reported health status is the lowest among the EU member states.

Although in Lithuania health expenditures per capita are very low comparing with the Nordic countries, the health care resources indicators are high, indicating low quality of health services and waste of resources. The indicators of health care resources, such as practicing doctors per 1000 population and hospital beds per 1000 population, are higher in Lithuania and Russia, comparing with some Nordic countries (Denmark, Iceland) and especially Poland, but, as the analysis of health status revealed, this is related with high sickness rates and not with good results of health improvement in Lithuania and Russia.

Therefore, although the number of hospital beds and practicing doctors per 1000 population in Lithuania is higher than in other countries, the efficiency of the health protection system is very low because of low financing, providing for low quality of health care services and providing that the cancer mortality rate in Lithuania is almost the highest in the EU. In addition, the mortality rates in Lithuania and Russia are the highest in the Baltic Sea Region, indicating low efficiency of health care system in both countries.

\section{Integrated indicators for assessment of health status, health care resources, health financing and determinants of health}

Health status, health resources, etc. can be measured by the set of specific indicators. Sometimes, based on the set of specific indicators, it is difficult to assess the overall efficiency of the health care system, as the indicators are provided for different and sometimes contradicting results. In this case, Multi-criteria methods can help a lot in providing the trade-off between the conflicting indicators, representing the specific issues of the assessment (Munda, 2005; Blancas et al., 2010; Mirshojaeian, Kaneko, 2011; Floridi et al., 2011; Shmelev, 2011).

The integrated assessment indicators are developed for monitoring success of implementing strategies and for assessment of policies and measures, seeking to reflect the main targets set in strategies or policy documents as well as for the comparison of countries in the achievement of certain aims. As the health protection efficiency and the increase of health status of the population are the main aims of the health care policy, the Baltic Sea region countries need to be compared according to their health status, health care re- 
sources, health financing and determinant of health, seeking to define the most efficiently functioning health protection system. Integrated indicators might be useful in this sense. Further, the integrated health indicators will be constructed from a wide range of specific indicators, allowing the indication of how the changes of the structural indicators of health influence the dynamics of the integrated indicator applied for the comparison and ranking of the Baltic Sea Region countries in their achievements of health care tasks.

The integrated assessment indicators are obtained by summing weighted indices of all health indicators per country:

$$
\mathrm{Q}_{\mathrm{j}}=\sum \mathrm{w}_{\mathrm{i}}^{*} \mathrm{Q}_{\mathrm{i},} \text {, where } \sum \mathrm{w}_{\mathrm{i}}=1
$$

Here, $Q_{j}$ is the integrated indicator for health assessment of the specific country $j$; $Q_{i j}$ - the index of the indicator i for the specific health issue $j ; w_{i}-$ the weight of the indicator $\mathrm{i}$ in the integrated indicator.

The indices for the integrated are derived by the following formula:

$$
\mathrm{Q}_{\mathrm{ij}}=\mathrm{q}_{\mathrm{ij}} / \mathrm{qi} \mathrm{i}_{\mathrm{vid}}
$$

Here, $Q_{i j}$ stands for the index of the indicator $i$ for the specific country $j ; q_{i j}-$ the value of the indicator $i$ for the specific issue $j$; $q_{i v i d}$ - the average value of the indicator $i$ for all countries.

If indictor decrease is positive in terms of the assessment, the indices of such indicators are integrated as inverted indices:

$$
\mathrm{Q}_{\mathrm{ij}}=1 / \mathrm{Q}_{\mathrm{ij}}
$$

Further, the integrated y assessment indicators approach was applied for the comparison of the Baltic Sea Region countries in terms of health indicators. The higher value of the indicator provides for a higher ranking of a country in terms of health status, health financing, health care resources and determinants of health. Four integrated health indicators were calculated based on the 1-3 formulas for the 11 Baltic Sea Region coun-

\begin{tabular}{|c|c|c|c|c|c|c|c|c|c|c|c|}
\hline & 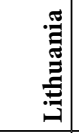 & 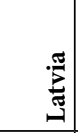 & 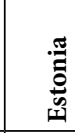 & 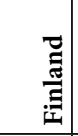 & 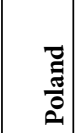 & $\begin{array}{l}\text { : } \\
\text { है: } \\
\text { है: }\end{array}$ & 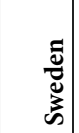 & 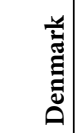 & 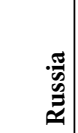 & $\begin{array}{l}\tilde{\Xi} \\
\tilde{E} \\
\tilde{E}\end{array}$ & 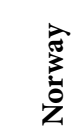 \\
\hline $\begin{array}{l}\begin{array}{l}\text { Health status } \\
\text { indicator }\end{array} \\
\end{array}$ & 1.07 & 11.92 & 13.67 & 19.44 & 14.22 & 22.33 & 21.26 & 20.85 & 13.93 & 23.96 & 21.23 \\
\hline $\begin{array}{l}\text { Determinants of } \\
\text { health }\end{array}$ & 87 & 2.63 & 2.81 & 3.23 & 2.95 & 2.83 & 3.86 & 2.97 & 2.96 & 4.31 & 3.41 \\
\hline $\begin{array}{l}\text { Health care } \\
\text { resources }\end{array}$ & 2.25 & 1.76 & 1.84 & 1.97 & 1.78 & 2.51 & 1.56 & 1.61 & 2.92 & 2.04 & 1.75 \\
\hline Health financin & 1.29 & 1.20 & 1.22 & 2.24 & 1.34 & 2.95 & 2.50 & 2.94 & 0.96 & 2.29 & 3.07 \\
\hline
\end{tabular}
tries and provided in Table 3.

Table 3. Integrated health indicators for the Baltic Sea Region countries in 2010 
The ranking of the Baltic Sea region countries according to the 4 integrated health indicators, representing health status, health care resources, health expenditures and determinants of health, are presented in Figures 2-5.

In Figure 2, the Baltic Sea region countries are ranked according to the health status indicators.

Figure 2. Ranking of the Baltic Sea Region countries according to the integrated health status indicator

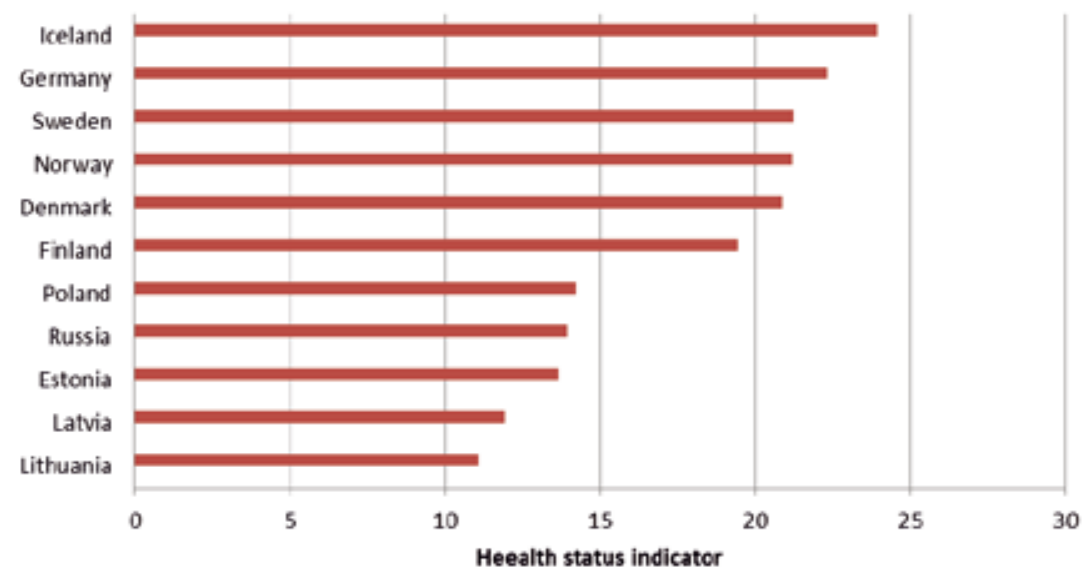

As it can be seen from Figure 2, according to the integrated health status indicators, Iceland, Germany, Sweden and Norway are the best performing countries. Lithuania is ranked as a country having the lowest health status indicator, following by Latvia and Estonia.

Figure 3. Ranking of the Baltic Sea region countries based on the integrated indicator of determinants of health

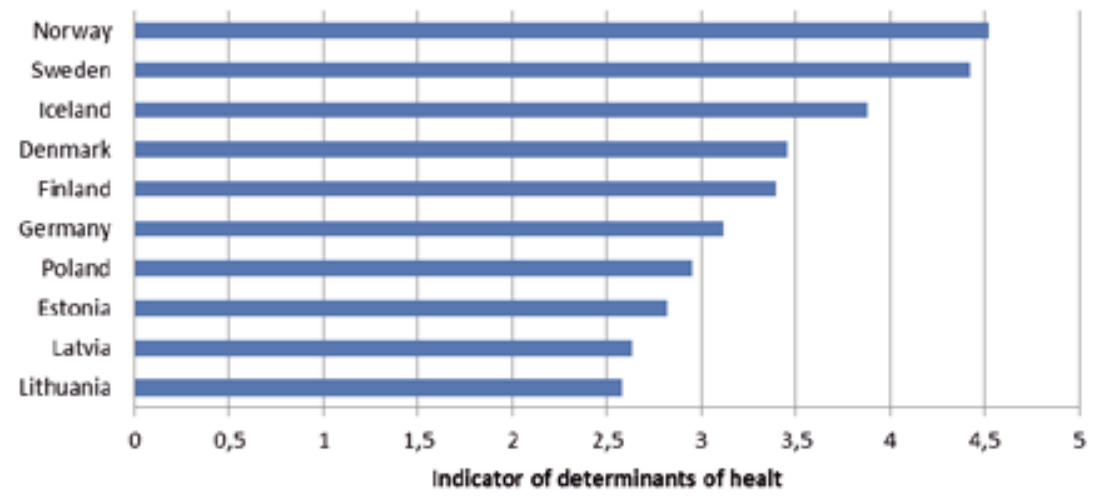


As it can be noticed from Figure 3, the best performing country in the Baltic Sea Region according to the integrated indicators of health determinants is Norway, followed by Sweden, Iceland and Denmark. Russia is ranked as the country having the lowest integrated indicator of health determinants, following by Lithuania.

Figure 4. Ranking of the Baltic Sea region countries based on the integrated health care resource indicator

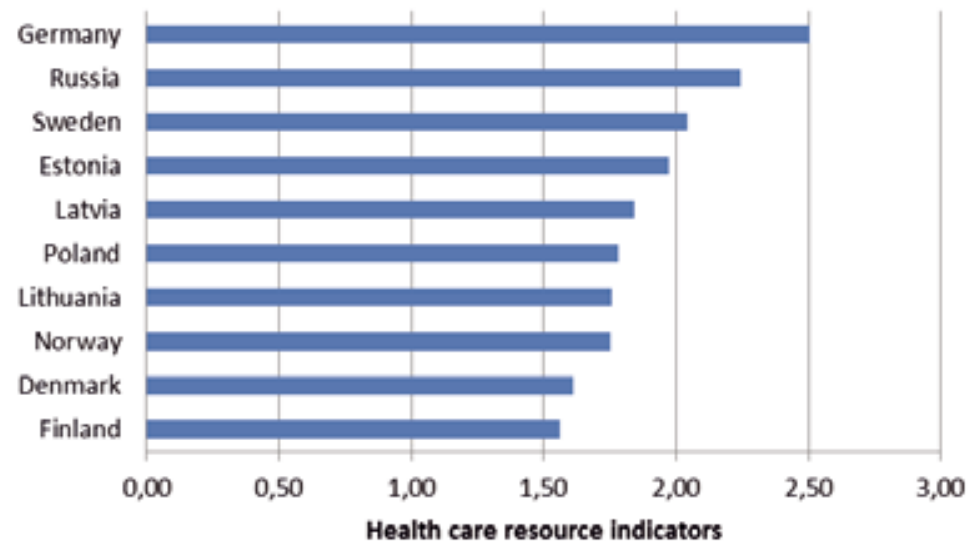

As it can be seen from Figure 4, Germany has the highest indicator of health care resources followed by Russia. Finland has the lowest health care resources indicator, following Denmark and Norway, indicating that the health care quality is high and the health care system is efficient, providing for good results in health care with comparatively low health care resources, such as practicing doctors or hospital beds per 1000 population.

Figure 5. Ranking of the Baltic Sea region countries based on the integrated health financing indicator

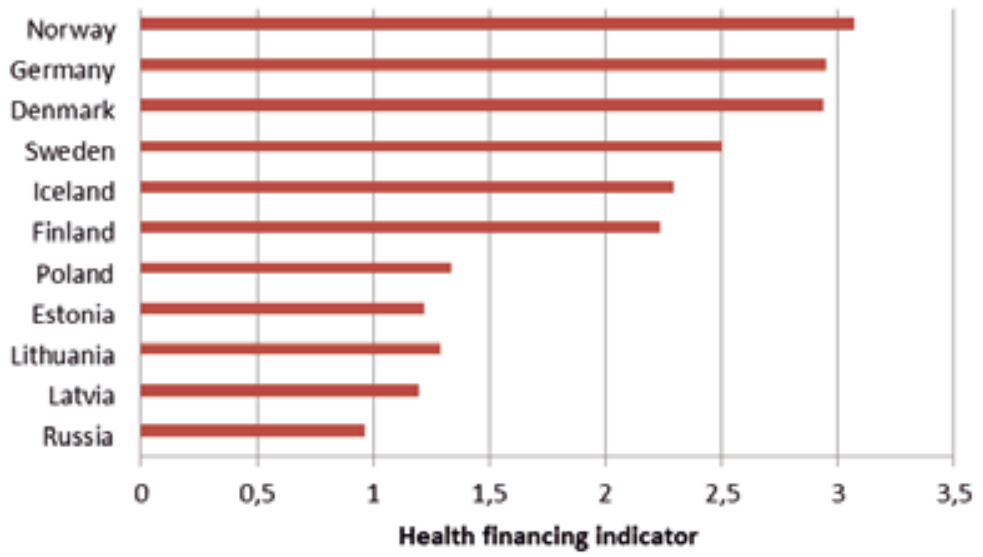


As it can be noticed from Figure 5, according to the integrated health financing indicator, the best performing country is Norway, followed by Germany, Denmark and Sweden. The worst performing country is Russia, following Lithuania.

\section{Lithuanian health protection system}

After the restoration of its independence in 1989, Lithuania inherited a centralized system that mainly delivered inefficient healthcare management and resource allocation. It opted for restructuring and decentralization as strategies that would increase the efficiency of health services. Decentralization of the healthcare system was achieved by segregating primary healthcare (family physicians), secondary healthcare (physiciansspecialists) and tertiary healthcare levels (high specialization university clinics). The development and reformation of the primary healthcare was seen as a key factor in the entire healthcare reform. The current situation implies that the Lithuanian health system is faced with a number of basic challenges, which might constrain its capability to experiment with innovative, ICT-based health services (Jakušovaite, Darulis, 2005).

The Ministry of Health is responsible for general supervision of the entire healthcare system. It is strongly involved in drafting legal acts and issuing the consequent regulation for the sector. There are 34 institutions, which are subordinate to the Ministry of Health, including 8 hospitals and clinics.

With the decline in scope of directly administered healthcare institutions, maintenance and development of tertiary healthcare became the focus of the administrative activities of the Ministry of Health. It now shares responsibility for running two major Lithuanian teaching hospitals with the State Vilnius University and the Kaunas Medical University.

In Lithuania, the main law on public health is the Law on Public Health Care, passed by the Seimas in 2002 and last amended in 2007, and it is implemented through a number of by-laws. The Law on Public Health Care (see Annex 3, Section 6) has three strands of action in the field of public health: the Public Health Strategy, the National Environment and Health Programme and the Children's Health Promotion Programme. Also, important strategic documents are the Lithuanian National Public Health Strategy 2006-2013 and its implementation plans for 2006-2008 and 2009-2013, which also define concrete measures on environmental health (World Health Organization, 2010).

The National Environment and Health Action Programme was developed and adopted according to Article 20 of the Law on Public Health Care. Adopted by the government in 2003, the NEHAP for 2003-2006 set the key framework policy for protecting and promoting Lithuania's population by improving environmental health management and the state of public health and by ensuring a safe environmental quality. The objectives of the NEHAP are defined as follows:

- Strengthen public health surveillance and environmental protection institutions and promote their cooperation;

- Integrate health and environment aspects into the main economic development programmes and strategies;

- Create awareness and understanding among politicians, specialists and the general population of the environmental health problems and their solutions; 
- Inform the public about the relationship between the environment and health and promote their participation in decision-making.

Until July 2010, at the regional level each of the ten counties had a county governor who was appointed by the Lithuanian Government and was responsible for implementation of state policy in a number of spheres, including healthcare. The healthcare function was carried out by the post of County Physician. Some healthcare providers (county hospitals, specialized healthcare facilities) were governed by the county administration. Decision-making in this network of providers required participation of the Ministry of Health. The counties were in charge of enforcement of the state health programmes in their respective regions. From July 2010, under the reform of counties, the administrations of counties were eliminated, and the healthcare institutions previously governed by county administration became accountable to the Ministry of Health or the municipalities.

The municipalities are responsible for providing primary healthcare to their local populations. They have been granted property rights for outpatient facilities and nursing homes. The municipalities are engaged in running small and medium sized hospitals within their localities, in accordance with legislation which has delegated this function to them.

Primary healthcare in Lithuania is provided in 452 state and 1284 private institutions. State institutions may be centers, general practitioners' offices, ambulatory clinics and polyclinics - general or specialized. Ambulatory clinics are usually in smaller towns, while polyclinics are situated in bigger cities, providing more complex services, such as outpatient surgery. Paramedical centers (medical posts) and health posts (community nurse) in schools also provide primary care in rural areas.

Half of the Lithuanian hospitals are general hospitals, and they have $67 \%$ of the country's hospital beds. There are also 36 specialized, three rehabilitation hospitals and 33 sanatoriums. Until July 2010, the Ministry of Health managed 13 of these national healthcare facilities directly. At the regional level, the county administrations with Ministry involvement governed some hospital and specialized care. The municipalities often ran small or midsized hospitals.

Family healthcare is based on the institution of a family physician. This position in Lithuania has been introduced taking into account the experience of other countries. Family physicians should maintain not only direct care activities like diagnosing and treating patients, but also target the health preservation and disease prevention functions. A family physician plays the role of a counselor or a coordinator guiding through the health system, offering the consultation on elementary health issues, monitoring the occurrence of chronic diseases and making the referrals for necessary specialist consultations. A licensed family physician takes care of the inhabitants registered at the primary healthcare facility (out-patient clinics, family doctor centers).

The European Council at the meeting in Luxembourg in 2006 adopted the document named 'Council Conclusions on Common values and principles in EU Health systems.' This document has been signed by all the then 25 member states of the EU, including Lithuania. The document states that the overarching values of the health care systems in Europe should be universality, access to good quality care, equity and solidarity.

The overarching goal of the reform and restructuring in all the Baltic countries also in Lithuania - is to provide cost-efficient and high quality healthcare services. This is planned to be achieved by strengthening primary healthcare, reducing hospital capacity and reforming finance. 
In January 2003, the Ministry of Health presented a project for the strategic restructuring of healthcare institutions to the government. The project identified three main directions for restructuring: further development of outpatient services with emphasis on primary healthcare; optimization of patient service and the development of alternative forms of activity; development of medical nursing and long-term care services with emphasis on services for the elderly.

The current reform allows complying with these values. Creation of three regions with 3R level hospitals and two regions with 3R2U hospitals will mean that $60 \%$ of the population will not have or will have difficult access to the university type of services and they will be quite distant from their homes (values of access to good quality care and equity will be undermined). The $2 \mathrm{U}$ concept involves exceptional financing of the university hospitals, thus widening the existing significant gap in the specialist working environment in different regions, and makes it difficult to implement the value of solidarity.

Since each stage of health care development since independence in 1990, the leading academics of these hospitals have been able to devise the means and tools to direct more finances to their hospitals, whether the funds be national, international or European. As a result of these policies, the regional hospitals are deprived not only of facilities, but also, and more importantly, of specialist care and input. With the implementation of the current reform, the problem of the lack of specialists in the regions will be further exacerbated.

The intended reduction of the hospitals, without involving specialists in the management of the hospitals, will mean further concentration of power by fewer individuals. This in turn will enhance the existing hierarchy and will lead to an even higher spread of corruption with the direction, which is opposite to the value of universality. The next question concerns the way the reform is carried out. All strategic planning experts state the simple rule that every reform should be conducted based on the principles of strategic planning. These principles state that the most important aspect is not the essence of the reform, but the way in which it is conducted. The restructuring plan was announced on September 8, 2009, and all stakeholders were given one week to express their views, concerns and suggestions.

An attempt to increase efficiency of Lithuanian health services has been a common goal over the last fifteen years in Lithuania. Decentralization was one of the strategies to achieve it. The Lithuanian National Board of Health encourages the decentralization and privatization of the institutions of primary health care and the centralization of the institutions of secondary health care. From 1994 to 1995, one of the political decisions was to devolve health care services by shifting administration from the Ministry of Health to the ten counties. At the same time, funding responsibilities were moved from the Lithuanian Ministry of Health to the State Sickness Fund. The counties are in charge of the enforcement of the state health programs in their respective regions. The municipalities are responsible for providing primary health care to their local population and are engaged in running small and medium size hospitals within their localities. Moreover, the municipalities have a wide range of responsibilities in the implementation of local health programs and the improvement of public health activities. Decentralization of management transfers responsibility to where the work is actually done, allowing for the search for optimal solutions for the achievement of the results of health promotion in real conditions. In essence, this would mean the development of a new managerial model that would clearly define 
the rights, responsibilities and accountability of the participants in the health promotion process (Kiskiene, Giest, Dumortier, 2010).

Despite increasing cooperation between administrators, providers and consumers, the latter remains the weakest in the bargaining process. The municipalities and county administrations do not have enough capacity to plan the services under their responsibility and appear to lack the authority to enforce their decisions. The municipalities responsible for maintaining and developing their respective health care infrastructure do not allocate sufficient resources for this purpose. A serious obstacle to the health care reform in Lithuania is a continuing lack of managerial skills and low interest in the application of professional expertise in decision-making. In addition, the municipalities that make decisions related to the development of primary healthcare services impede private capital investment. Municipal Councils that make such decisions demonstrate significant lobbying of state institutions. Lithuanian Law of Health Care Institutions allows permitting or depriving the establishment of private health care institutions. Thus, there is an obvious gap between the aims of the healthcare reform policy and the expectations of the patients.

The annual report of the National Health Council states that the network of stationary healthcare institutions is excessive and irrational. Due to the lack of medical technologies and human resources, healthcare institutions of a lower level cannot ensure quality of healthcare. At present, certain hospitals perform one or two complex operations or procedures per year. In the absence of a sufficient number of operations or procedures, discussions about the quality of service become complex. The report indicates that Lithuania should adopt the model that proved to be optimal in the world and Europe, i.e. merging of hospitals rather than closing them. This would preserve human resources, modern technologies and the experience of the merged hospitals. The main issue of the opponents of this model is the assurance of the accessibility of healthcare services in a geographical/territorial sense.

It is very difficult to explain to people in the regions that although they have mandatory health insurance, they cannot sometimes get one or other service they had before. This situation raises social problems, as well; not every patient can afford paying for the trip to the needed specialist, who works in a higher-level institution in the district centre or some big city. But the problem is more complex. There are over 29.990 hospital beds in Lithuania. Comparing hospital cases per 1000 inhabitants with the same in Sweden, it is becoming clear that in Sweden 3600 hospital beds would be enough for the same treatment. This situation exists because a lot of patients are treated in Lithuanian hospitals, while in Sweden and other countries many more would be treated in outpatient. In addition, Lithuanian secondary health service is highly institutionalized; there is no outpatient care or nursing. This model of treatment raises the threat of ageism, disturbance of human dignity and other problems.

\section{Conclusions}

1. The Nordic model of health care is characterized by funding predominantly by taxes, decentralized public governance structure (except Norway from 2002), elected local governments that can tax, public ownership (or control) of de- 
livery structure, equity driven, with focus on geographical and social equity, public participation.

2. Comparing the main health indicators between Lithuania and other EU members states, low health expenditure rates per capita in Lithuania are available. Health expenditures per capita in Lithuania makes 972 EUR adjusted at PPP or $7 \%$ of GDP. In Denmark, health expenditures per capita in 2010 was equal to 3439 EUR PPPS or 9\% of GDP. In addition, the adults self-reported health status in Lithuania is the lowest among the EU member states. Only $52 \%$ of the population reported about good health in Lithuania in 2010. In Denmark, more than $70 \%$ and in Finland almost $70 \%$ of the population self-reported that they are healthy.

3. Although health expenditures per capita in Lithuania are very low comparing with the Nordic countries, the health care resources indicators are high, indicating low quality of health services and waste of resources. Therefore, although hospital beds and practicing doctors number per 1000 population in Lithuania is higher than in other countries, the efficiency of the health protection system is very low because of low financing, providing for low quality of health care services and providing that cancer mortality rate in Lithuania is almost the highest in the EU. In addition, the mortality rates in Lithuania and Russia are the highest in the Baltic Sea Region, indicating low efficiency of health care systems in both countries.

4. Integrated health indicators framework was developed to assess the impact of the health protection system and health determinants on health status in the Baltic Sea Region. The analysis revealed that high rates of financing of the health protection system available in Norway, Germany, Denmark, Sweden and other Nordic countries provides for the best results in health status in these countries. Other important factors are health determinants and countries having the best rating according to the integrated indicator of health determinants (Norway, Sweden, Iceland and Denmark) have the best health status indicators.

5. The high health care resources indicators do not provide for good health status in countries, such as Russia and Lithuania, having the lowest financing rates, the health determinants and health status indicators.

6. The regulatory situation in the Lithuanian health protection system is rather adequate, and it benefits significantly from the development of the European Union legal requirements. Although improvements are still necessary in particular areas, the main challenge for Lithuania is to implement and execute the regulations to monitor their implementation and to evaluate the effectiveness of both the regulations and their implementation.

7. An attempt to increase efficiency of Lithuanian health services has been a common goal over the last fifteen years in Lithuania. Decentralization was one of the strategies to achieve it. A situation of centralization in the health care is much the same. Although the centralization of the institutions of the secondary health care in Lithuania was successful in improving the quality of services, many issues remain unsolved. The annual report of the National 
Health Council states that the network of stationary healthcare institutions is excessive and irrational. Due to the lack of medical technologies and human resources, healthcare institutions of a lower level cannot ensure quality of healthcare.

8. Collaboration between ministries and stakeholders does exist to varying degrees and on different levels of the health protection system and several intersectional committees have successfully been set up to manage ongoing policy processes. In general, the Ministry of Health handles environment and health issues, and the integration of non-health sectors needs to be strengthened. This is especially relevant in view of the current lack of accountability for actions on the environment and health in non-health sectors.

\section{References}

1. Blancas, F. J.; Caballero, R.; González, M.; Lozano-Oyola, M. and Pérez, F. Goal Programming Synthetic Indicators: An Application for Sustainable Tourism in Andalusian Coastal Counties. Ecological Economics. 2010, 69(11): 2158-2172.

2. Eest Koosto Kogu. Estonia Human Development Report. Baltic Way(s) of Human Development: Twenty Years On. 2011.

3. European Observatory on Health Care Systems. Health Care Systems in Transition: Lithuania. Copenhagen, WHO Regional Office for Europe, 2000 [interactive]. [accessed on 01-03-2010]>. [http://www.euro.who.int/Document/E69920.pdf].

4. Floridi, M.; Pagni, S.; Falorni, S. and Luzzati, T. An Exercise in Composite Indicators Construction: Assessing the Sustainability of Italian Regions. Ecological Economics. 2011, 70(8): 1440-1447.

5. Health Consumer Powerhouse. Euro Health Consumer Index. European Commission, Information Society and Media. 2008 [interactive]. [accessed on 20-01-2010]. <http:// www.healthpowerhouse.com/files/2008-EHCI/EHCI-2008-index-03.pdf>.

6. Hammitt, J. and Graham, J. D. Journal of Risk and Uncertainty. 1999, 8: 33-62,

7. Johanesson, M.; Johansson, P. O. and Lofgren, K. G. On the Value of Changes in Life Expectancy: Blips Versus Parametric Changes. Journal of Risk and Uncertainty. 1997, 15: 221-239.

8. Jakušovaitè, I. and Darulis, Ž. Lithuanian Health Care in Transitional State: Ethical Problems. BMC Public Health. 2005 (117).

9. Kidholm, K. Assessing the Value of Traffic Safety Using the Contingent Valuation Technique: The Danish Survey, in Swab Christie, N. and Soguel, N. (eds.). Contingent Valuation, Transport Safety and the Value of Life. The Netherlands: Kluwer Academic Publishers, 1995, 45-61.

10. Kiskiene, S. and Giest, J. Dumortier. Country Brief: Lithuania, E Health Strategies, EC, DG Information Society and Media, ICT for Health Unit. 2010.

11. Krupnick, A. and Cropper, M. The Effects of Information on Health Risk Valuations. Journal of Risk and Uncertainty. 1992, 5: 29-48. 
12. Mirshojaeian Hosseini, H. and Kaneko, S. Dynamic Sustainability Assessment of Countries at the Macro Level: A Principal Component Analysis. Ecological Indicators. 2011, 11(3): 811-823.

13. Munda, G. "Measuring Sustainability“: A Multi-Criterion Framework. Environment, Development and Sustainability. 2005, 1 (7): 117-134.

14. OECD. Health at a Glance Europe. 2012.

15. Patrick, D. L. and Erickson, P. Health Status and Health Policy. Quality of Life in Health Care Evaluation and Resources Allocation. New York: Oxford University Press, 1993.

16. Perleth, M.; Jakubowski, E. and Busse, R. What Is 'Best Practice' in Health Care? State of the Art and Perspectives in Improving the Effectiveness and Efficiency of the European Health Care System. Health Policy. 2001, (56, 3): 235-250.

17. Shmelev, S. E. Dynamic Sustainability Assessment: The Case of Russia in the Period of Transition (1985-2008). Ecological Economics. 2011, 70(11): 2039-2049.

18. World Health Organization Europe. Environment and Health Performance Review. Lithuania. 2010. indicator.

NOTE: Figure 2: heealth - health, Figure 3: healt - health, Figure 4: indicators -

\section{LIETUVOS IR BALTIJOS JŪROS ŠALIŲ SVEIKATOS APSAUGOS SISTEMŲ PALYGINIMAS}

Santrauka. Pagrindinis socialinis darnaus vystymosi tikslas yra gyventojų sveikatos sąlygų gerejimas bei efektyvios sveikatos apsaugos sistemos plètra. Efektyvi sveikatos pasaugos sistema siekia užtikrinti adekvačią sveikatos apsaugą ir gyventojų sveikatos būklès gerèjimą. Tačiau investicijos ị sveikatos apsaugą, sveikatos apsaugos specialistų kompetencijos didinimą, infrastruktūros plètrą, bendruomenès sveikatos gyvensenos būdo ugdymą ir kt. duoda labai skirtingus rezultatus skirtingose Baltijos jūros regiono šalyse, todèl svarbu nustatyti tų skirtumų priežastis bei ịvertinti sveikatos apsaugos sistemų Baltijos jūros regiono šalyse efektyvumą bei pagrindinius gyventoju sveikatos būklès skirtumus lemiančius veiksnius.

Straipsnio tikslas - išnagrinèti sveikatos apsaugos išteklių bei sveikatos apsaugos sistemų įtaką sveikatos būklès rodikliams Lietuvoje ir kitose Baltijos jūros šalyse.

Pagrindiniai uždaviniai siekiant nustatyto tikslo yra:

palyginti sveikatos apsaugos išteklius ir šalies skiriamą finansavimą sveikatos apsaugos sistemoms Lietuvoje ir kitose Baltijos jūros regiono šalyse;

palyginti pagrindinius sveikatos būklès rodiklius Lietuvoje ir kitose Baltijos jūros regiono šalyse;

nustatyti sveikatos apsaugos sistemų efektyvumą siekiant užtikrinti gyventojų sveikatos būklès gerẻjimą Lietuvoje ir kitose Baltijos jūros regiono šalyse .

išnagrinèti Lietuvos sveikatos apsaugos sistemos pagrindinius bruožus ir nustatyti pagrindinius trūkumus bei aptarti tyrimo rezultatus. 
Dalia ŠTREIMIKIENĖ - Habil. Dr. in Economics, professor of Institute of Economics and Business, Faculty of Economics and Finance Management, Mykolas Romeris University. Scientific research area - sustainable energy, energy policy, climate change mitigation policies, international trade and economics.

Dalia ŠTREIMIKIENĖ - Mykolo Romerio universiteto Ekonomikos ir finansų valdymo fakulteto Ekonomikos ir verslo instituto profesoré, ekonomikos mokslų habilituota daktarè. Mokslinių tyrimų sritys: darni energetika, energetikos politika, klimato kaitos švelninimo politika, tarptautine prekyba ir ekonomika.

Justas ŠTREIMIKIS - Lithuanian University of Health Sciences. Scientific research area: health of the population.

Justas ŠTREIMIKIS - Lietuvos sveikatos mokslų universitetas. Mokslinių tyrimų sritis: visuomenès sveikata. 